\title{
IfIISGUC.ORG
}

"iș, GÜç̣" ENDÜSTRi iLișKiLERi VE inSAN KAYNAKLARI DERGisi

"IS, GUC" INDUSTRIAL RELATIONS AND HUMAN RESOURCES JOURNAL

\section{İş Sağlığı ve Güvenliğinde Psikolojik Bir Yaklaşım: Atıf Kuramı}

\author{
A Psychological Approach to Occupational Health and Sa- \\ fety: Attribution Theory
}

Yrd.Doç.Dr.Barış SEÇER

Dokuz Eylül Üniversitesi, İ̈BF, Çalışma Ekonomisi ve Endüstri İlişkileri Bölümü

Ekim/October 2012, Cilt/Vol: 14, Say1/Num: 4, Page: 29-46

ISSN: 1303-2860, DOI: 10.4026/1303-2860.2012.0209.x

Makalenin on-line kopyasına erişmek için:

http://www.isguc.org/?p=article\&id=497\&vol=14\&num=4\&year=2012

To reach the on-line copy of article:

http://www.isguc.org/?p=article\&id=497\&vol=14\&num=4\&year=2012

Makale İçin İletişim/Correspondence to: 
(c) 2000- 2012

"İ̧̧üç̧" Endüstri İlişkileri ve İnsan Kaynakları Dergisi

"İşǚç" Industrial Relations and Human Resources Journal

Ekim/October 2012, Cilt/Vol: 14, Say1/Num: 4
ISSN: 1303-2860, Journal DOI: 10.4026/1303-2860

İş,Güç, Endüstri İlişkileri ve İnsan Kaynakları Dergisi, yılda dört kez yayınlanan hakemli, bilimsel elektronik dergidir. Çalışma hayatına ilişkin makalelere yer verilen derginin temel amacı, belirlenen alanda akademik gelişime ve paylaşıma katkıda bulunmaktadır.

İş, Güç, Endüstri İlişkileri ve İnsan Kaynakları Dergisi, 'Türkçe’ ve ‘İngilizce' olarak iki dilde makale yayınlanmaktadır.

Dergimiz İş,Güç ulusal ve uluslararası birçok indekste taranmaktadır. (Cabells Directory, Ebsco Socindex, Index Islamicus, Index Copernicus, Worldwide Political Science Abstracts, Sociological Abstract, Ulakbim Sosyal Bilimler Veritanı, Asos Index)

Editör/Editor-in-Chief

Aşkın Keser (Uludağ University)

Editör Yardımcılarn/Co-Editors

K.Ahmet Sevimli (Uludağ University)

Gözde Yilmaz (Marmara University)

Uygulama/Design

Yusuf Budak (Kocaeli Universtiy)

Tarandiğı Indeksler

ASOS INDEX

CABELLS DIRECTORY

EBSCO SOCINDEX

Index ISLAMICUS

Index COPERNICUS

Sociological Abstract

ULAKBIM Sosyal Bilimler

Veritanı

Worldwide Political Science

Abstracts

\author{
Yayın Kurulu / Editorial Board \\ Yrd.Doç.Dr.Zerrin Furat (Uludă̆ University) \\ Doç.Dr.Aşkın Keser (Uludağ University) \\ Prof.Dr.Ahmet Selamoğlu (Kocaeli University) \\ Yrd.Doç.Dr.Ahmet Sevimli (Uludağ University) \\ Doç.Dr.Abdulkadir Şenkal (Kocaeli University) \\ Doç.Dr.Gözde Yılmaz (Marmara University) \\ Dr.Memet Zencirkıran (Uludağ University)
}

Uluslararası Danışma Kurulu / International Advisory Board Prof.Dr.Ronald Burke (York University-Kanada)

Assoc.Prof.Dr.Glenn Dawes (James Cook University-Avustralya)

Prof.Dr.Jan Dul (Erasmus University-Hollanda)

Prof.Dr.Alev Efendioğlu (University of San Francisco-ABD)

Prof.Dr.Adrian Furnham (University College London-İngiltere)

Prof.Dr.Alan Geare (University of Otago- Yeni Zellanda)

Prof.Dr. Ricky Griffin (TAMU-Texas AEM University-ABD)

Assoc. Prof. Dr. Diana Lipinskiene (Kaunos University-Litvanya)

Prof.Dr.George Manning (Northern Kentucky University-ABD)

Prof. Dr. William (L.) Murray (University of San Francisco-ABD)

Prof.Dr.Mustafa Özbilgin (Bruner University-UK)

Assoc. Prof. Owen Stanley (James Cook University-Avustralya)

Prof.Dr.Işık Urla Zeytinoğlu (McMaster University-Kanada)

Ulusal Danışma Kurulu I National Advisory Board
Prof.Dr.Yusuf Alper (Uludă̆ University)
Prof.Dr.Veysel Bozkurt (İstanbul University)
Prof.Dr.Toker Dereli (Işık University)
Prof.Dr.Nihat Erdoğmuş (İstanbul Şehir University)
Prof.Dr.Ahmet Makal (Ankara University)
Prof.Dr.Ahmet Selamoğlu (Kocaeli University)
Prof.Dr.Nadir Suğur (Anadolu University)
Prof.Dr.Nursel Telman (Maltepe University)
Prof.Dr.Cavide Uyargil (İstanbul University)
Prof.Dr.Engin Yildırım (Anayasa Mahkemesi)
Doç.Dr.Arzu Wasti (Sabancı University)

Dergide yayınlanan yazılardaki görüşler ve bu konudaki sorumluluk yazarlarına aittir.

Yayınlanan eserlerde yer alan tüm içerik kaynak gösterilmeden kullanılamaz.

All the opinions written in articles are under responsibilities of the outhors.

The published contents in the articles cannot be used without being cited. 


\title{
İş Sağlığı ve Güvenliğinde Psikolojik Bir Yaklaşım: Atıf Kuramı
}

\author{
A Psychological Approach to Occupational Health and Safety: \\ Attribution Theory
}

\author{
Yrd.Doç.Dr.Barış SEÇER \\ Dokuz Eylül Üniversitesi, İ̈BF, Çalışma Ekonomisi ve Endüstri İlişkileri Bölümü
}

\begin{abstract}
Özet
Psikolojik kuramlar ve araştırmalar, iş sağlığı ve güvenliği alanına önemli katkı sağlamaktadır. Atıf kuramı iş̧̧ilerin, yöneticilerin, uzmanların iş kazaların hangi faktörlere atfettiklerini incelemekte kullanılmaktadır. İş̧iler, yöneticiler ve uzmanlar kazalara yönelik kişisel (içsel) ve kişidışı (dışsal) nedenlere atıflar yapabilmektedir. Bu atıfları etkileyen; sebebin kalıcıliğı, sebebin kontrol edilebilmesi gibi boyutlar bulunmaktadır. Ayrıca işçiler bu boyutları değerlendirerek, kaza sonrası tutum ve davranışların belirlemektedir. Bazı durumlarda ise, yöneticiler ve iş arkadaşları tarafindan iş kazasının sorumluluğu iş̧̧inin kendisine veya durumsal faktörlere yüklenebilmektedir. Dolayısıyla, atıf kuramı işçilerin güvenlik davranışlarının anlaşılmasını sağlamaktadır.
\end{abstract}

Anahtar Kelimeler: Atıf kuramı, Kişisel ve Kişidışı Atıflar, Temel Atıf Hatası, Aktör-gözlemci Etkisi, Benliğge Hizmet Eden Yanliliklar

\begin{abstract}
Psychological theories and researches have important contributions to occupational health and safety. The attribution theory is used for to investigate to which factors the occupational accidents are attributed by workers, managers and experts. Workers, managers and experts can make attributions to the individual (internal) and impersonal (external) causes. There is some dimensions that effects this attributions as causal stability and causal controllability. Evaluating these dimensions, workers determines their after accident attitude and behaviors. In some cases, responsibility of occupational accident can be ascribed to workers by their managers and co-workers. Thus, the attribution theory provides to understand the safety behaviors of workers.
\end{abstract}

Keywords: Attribution theory, personal and impersonal attribution, fundamental attribution error, actor-observer effect, self-serving bias 


\section{Giriş}

İş sağllğ 1 ve güvenliği alanı, işçi davranışları ile ilgili değerlendirmelerinde psikoloji biliminden yararlanmaktadır. Özellikle atıf kuramı, iş kazalarının nedensel atıf süreçleri ile ilgili bilgi sağlamaktadır. Atıf kuramında, insan davranışları ve olaylar bir takım faktörlere dayandırılmaktadır. Bu faktörlerin belirlenmesi ile kişiye özgü ve kişidışı faktörler ayrımı yapılması, is sağlığ 1 ve güvenliği uygulamalarına önemli katkı sağlayabilecektir. Örneğin işçiler, yöneticiler, uzmanlar ve kaza sorușturmacıları herbiri iş kazaları için farklı nedensel atıflar yapabilmektedir. Bu durum, iş sağlığ1 ve güvenliği önlemlerinin belirlenmesinde ve uygulanmasinda sorun yaratabilmektedir.

Ayrıca işçi, yönetici ve uzmanların yaptıkları atıflar çeşitli bireysel ve örgütsel faktörlerden etkilenmektedir. Bu faktörlerin neler olduğunun incelenmesi ve iş sağ $\operatorname{llğ}_{1}$ ve güvenliği ile ilgili değerlendirmelerin bu doğrultuda yapılması gereklidir. Yaş, iş doyumu, kültür gibi birçok faktör nedensel atıfları etkilemektedir. Literatürde bu faktörleri inceleyen araştırmalara rastlanmaktadır. Çalışmamızın amacı bu faktörleri inceleyerek, iş sağllı̆̆ ve güvenliği açısından psikolojik yaklaşımlardan atıf kuramına dikkat çekmektir. Çalışmanın ilk bölümünde atıf kuramına değinilecek, daha sonra iş sağlığ1 ve güvenliği açısından atıf kuramı değerlendirilecektir. Son olarak nedensel atıfların iş kazası sonrası etkileri açıklanacaktır.

\section{İş Sağlığı ve Güvenliğinde Psikolojik Yaklaşımlar}

İş sağlığı ve güvenliği alanı sadece mühendislik yaklaşımlarını içermemektedir. İş kazalarının büyük bir çoğunluğu teknik nedenlerle birlikte insan faktörüne bağlanabilmektedir. Örneğin bazı araştırmalar iş kazalarının \%80'i, uçak kazalarının \%50'si ve nükleer kazaların \%50-70'inin insan hatalarına bağlı olduğunu göstermektedir. Dolay1sıyla iş sağlığı ve güvenliği alanında teknolojik çözümlerin yeterli olmadığı anla- ş1lmaktadir (Lingard ve Rowlinson,2005:231). İşletmelerdeki iş güvenliği uygulamaları, doğrudan işçileri yani insanları hedeflediği için, psikoloji biliminin iş sağlığ ve güvenliği alanına önemli katkıları olabilecektir. İşçilerin iş sağlığ 1 ve güvenliği kurallarına bazı önyargıları nedeniyle uymamaları, riskleri ve kaza nedenlerini farklı biçimlerde algılamaları gibi konular psikoloji bilimi yardımıyla açıklanabilmektedir.

Gerçekten insanların bazı özellikleri iş kazaları ve sağlık sorunlarına neden olabilmektedir. Örneğin işçiler işleri ile ilgili tehlikelerin farkında olmadıklarında veya riskleri önemsemediklerinde güvensiz davranışlar ortaya çıkabilmektedir. İşçiler koruyucu ekipman kullanma gibi güvenlik prosedürlerini sert karakterliliğe (maçoluk) ters olarak değerlendirebilmektedir. Bazı işçiler ise eve erken gitmek veya prim kazanmak gibi kişisel faydalar sağlamak için güvenlik prosedürlerine uymaktan kaçınabilmektedir. Zaman baskısının olduğu durumlarda ise, işçiler işleri kestirmeden hallederek ve iş güvenliğini tehlikeye atarak işi zamanında bitirmeye çalışabilmektedir. Kısaca insanlar yorgunluk veya başka konulardaki endișeleri nedeniyle yanılabilmekte ve tahmin edilemez şekilde davranabilmektedir (Lingard ve Rowlinson,2005:231). Bu bağlamda, üretim sürecinde insan ögesinin önemi, iş güvenliği uygulamalarının başarıya ulaşabilmesi için insan davranışının anlaşılması gerekliliğini doğurmaktadır. İnsan davranışının nedenlerini ortaya koymak için atıf kuramı gibi çeşitli kuramlar ileri sürülmüştür.

\section{Atıf Kuramı}

Atıf kuramı, temelde araştırmacıların davranışı anlamayı kolaylaştırmak ve gelecekteki davranışı biçimlendirmek için nedensel açıklamalar bulmaya çalışmaları ile ilgilidir. Kuram, günümüzde çeşitli konuların araştırmasında kullanılmaktadır. Özellikle örgütsel boyutta tükenmişlik ve iş doyumu konularında araştırmalar yapıldığı 
ve kuramın örgüt literatürüne girdiği görülmektedir. Ayrıca atıf kuramının iş güvenliği açısından ele alındığ 1 ve kapsamlı bir literatürün oluştuğu anlaşılmaktadır.

Heider, atıf kuraminın kurucusu olarak kabul edilmektedir. Heider, her insanın davranışı açıklamada kullandığ 1 bir genel kuramı olduğuna inanmaktadır. İnsanlar deprem, sel, fırtına gibi doğa olayları ve kızgınlık, öfke, sahtekarlık gibi insan davranışları için açıklamalar getirir. Genelde bu açıklamalar nedensel açıklamalardır ve belli şartlara belli bir nedensel rol atfedilir (Arkonaç,2005:131). Heider, insanların dünyanın işleyişine doğrudan değil, bu işleyişi algılamalarına göre tepkide bulunduklarını vurgulamaktadır. Bireylerin dünyalarını yapılandırmakta kullandıkları açıklamalar, ona tepki vererek uyum sağlayacakları mantıklı stratejiler için çok önemlidir (Rogers,2003:147).

Heider'e göre, insanlar atıflarda bulunarak iki temel gereksinimlerini giderirler: tutarlı, dengeli bir dünya görüşüne sahip olabilmek ve çevreleri üzerinde kontrol elde edebilmek. Bu gereksinimleri giderebilmenin bir amac1, insanların nasıl davranacaklarını öngörmektir (Kağıtçıbaş1,2004:228). Gerçekten modern atıf kuramında, çelişkinin azaltılması (tutumlar ve davranışlar arasındaki çatışma) veya yüksek amaçların başarılması, dengeye ulaşılması anlamındadır. Böylece atıf süreci ilk olarak, bireyin olayları tahmin etmesini mümkün kılmakta ve ikinci olarak olaylar üzerinde kontrol sağlamasına yardımcı olmaktadır. Atfetme kuramında kontrol ihtiyacı temel motivasyondur ve olayları tahmin etme bu kontrolü kolaylaştırmaktadır. Şekil 1'de atıf sürecindeki olayların sırası gösterilmektedir (Glendan ve diğ.,2006:83).

Şekil 1'de görülebileceği üzere, iç veya dış kaynaklı enformasyon, inançlar tarafından yeniden düzenlemekte, inançlar bilişi yap1landırmakta ve biliş de davranışı belirlemektedir. Heider ayrıca, bir olay için iki ana atıf türü ayrımı yapmıştır: kişisel atıflar (belli bir kişi sorumlu görüldügüunde veya suçlan-

\section{Şekil 1}

Genel Atıf Süreci

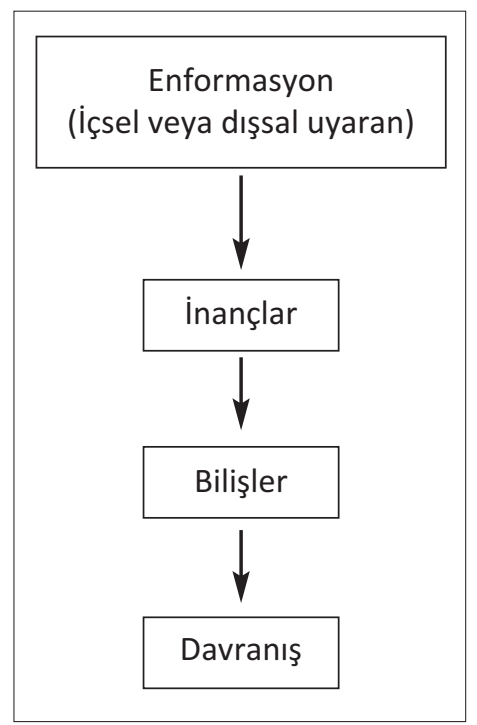

Kaynak: Glendan ve diğ.,2006:86.

dığında) ve kişidışı atıflar (hiçkimse suçlu veya sorumlu görülmüyorsa). Kişidışı atıflar kendiğilinden fakat aynı zamanda kasıtlı olmayan eylemlerden kaynaklanan olaylara yapılmaktadır. Kișisel atıflar ise, her zaman kasıtlı bir eylem anlamı taşımaktadır (Rogers,2003:147).

Weiner, Heider'in modelini genişleterek, insanların bu tür atıflarlarda bulunurken üç boyutu göz önünde bulundurduklarını öne sürer. 1) Sebebin konumu: sebep içsel mi, yoksa dişsal mı?, 2) Sebebin kalıcı veya geçici oluşu: İçsel veya dışsal sebepler kalıcı sebepler mi? Yoksa geçici sebepler mi?, 3) Sebebin kontrol edilebilirliği: Kişi gelecekte performansinı ne derecede kendi kontrolü altına alabilecek? (Arkonaç, 2005:141).

Weiner ayrıca bu üç boyutun genel motivasyon kuramı için rolünü belirlemiştir: 1) Sebebin konumu: Başarı kişilik, yetenek veya çaba gibi bir faktöre yani içsel atfediliyorsa, dişsal atfetmeye (görevin kolaylı̆̆ı, şans vb.) göre daha fazla özsaygı sağlamaktadır. Weiner başarısızlığın içsel olarak atfedilmesinin ise, dişsal atfetmeye göre daha düşük özsaygıya neden olacağını belirtmek- 
tedir. 2) Sebebin kalıcı veya geçici oluşu: Weiner'e göre, başarısızlık içsel ve kalıcı nedenlere atfediliyorsa, bunun umutsuzluk gibi duygusal tepkiler ile bağlantılandırılabileceğini ileri sürmektedir. 3) Sebebin kontrol edilebilirliği: Kişisel başarısızlık, diğerleri tarafından kontrol edilebildiği algılanan nedenlerden dolayı ise, kızgınlık ortaya çıkacaktır (Manstead ve Hewstone,1999:69-70). Buradan anlaşılacağ şılaşılan olayın değerlendirilmesi ve sonrasinda verilen tepkiler üzerinde etkilidir.

Atıf kuramına önemli katkıda bulunan Kelley'e göre, gözlemci aktörün davranışlarını değerlendirirken üç tür enformasyonu kullanır. Bunlar tutarlılık, ayırtedicilik ve konsensüs ölçütleridir. Birinci ölçüt, bir uyaranın farklı zaman ve durumlarda sürekli olarak aynı tepkiye yol açıp açmamasıdır; tutarlılık arttıkça nedenselliğin uyarana yüklenme olasılığı artar. İkinci ölçüt, bir uyarana tepkinin diğer uyaranlardan farklı olup olmaması ile ilgilidir ve uyaran bu bakımdan diğerlerinden ayırtedildikçe uyarana atıf olasılığı artar. Üçüncü ölçüt, aynı bir uyarana bireyin ve diğerlerinin tepkilerinin benzer olup olmamasıyla ilgilidir ve benzerlik arttıkça uyaranın neden olarak görülme olasilığ1 artar (Bilgin,2003:39).

Atıf kuraminda önemli bir konu da, atıf yanlılıklarıdır. Atıf süreçlerinde insan fazlasıyla rasyonel ve akılcı olarak görülmektedir. Halbuki insan, çabucak sebep yüklemekte, çok az bilgi kullanmakta ve teklif edilen belli tip açıklamalara (stereotipler, önyargılar gibi) açıkça eğilim göstermektedir. Bu eğilimleri sebep atfemede bir yanl1lik olarak gören sosyal psikologlar, atıflardaki bu muhtemel hataları incelemişlerdir. İnsanların sebep atıflarında en çok kullandıkları yanlılıklar: temel atıf hatası, aktör-gözlemci etkisi, hatalı benzerlik etkisi, benliğe hizmet eden yanlılıklar ve gruba hizmet eden yanlılıklardır (Arkonaç,2005:143).

Atıf kuramından, örgüt araştırmalarında giderek daha fazla yararlanılmaktadır. Özellikle risk alma davranışı ve kaza nedenleri gibi sosyal olaylar hakkında genel olarak paylaşılan inançların sosyal açıklamaları için kuramdan faydanılmaktadır. Görgül araştırmalar, işçilerin risk algılamaları ve nedensel atıflarının iş kazaları ve güvenlik iklimi üzerinde etkili olduğunu göstermektedir (Gyekye,2010:407). Ayrıca güvenlik ikliminin de nedensel atıfları etkilediği belirtilmektedir. Kısacası atıf kuramı iş güvenliğ $i$ açısından işçilerin davranışlarını değerlendirmekte önem taşımaktadır.

\section{İş Sağlığı ve Güvenliği Açısından Atıf Kuramı}

Daha önce değinildiği üzere, kaza nedenlerinin çoğu, doğası gereği davranıșsaldır. İş kazaları risk davranışlarından kaynaklanır. Risk davranışları azalırsa güvenli davranış artacak ve iş kazaları önlenebilecektir. Son yıllarda davranış temelli güvenlik araştırmaları çalışanların risk alma davranışını azaltmak ve güvenli davranışlarını artırmak için tasarlanmış müdahalelerin etkisini değerlendirmektedir (Geller,2001:143). Bu bağlamda, atıf kuramı işçilerin risk davranışları ve güvenli davranışlarını açıklama potansiyeli taşımaktadır. Ayrıca bununda ötesinde iş kazaları sonrasında kurban işçilerin işe dönme eğilimleri ve örgütsel bağlllık vb. durumların değerlendirilmesini sağlamaktadır.

Atıf kuramı, özellikle işçilerin ve yöneticilerinin iş kazalarının nedenlerini içsel (kişisel) ve dişsal (kişidışı) nedenlere bağlamaları açısından değerlendirilmektedir. Sosyal psikologlar alışılmamış kötü sonuçları olan deneyimler yaşamanın, bu deneyimlerin nedenleri ve amaçları için varoluşçu bir arayışı ortaya çıkardığını ve savunmacılığa yol açtığını gözlemlemişlerdir. İş kazaları da bu yaklaşıma uygun özellik göstermekte ve kazalar işçileri nedensel açıklamalar bulmaya teşvik etmektedir (Gyekye,2010:407). Gerçekten işçiler, beklenmeyen iş kazalarının kurbanı veya şahitleri olarak kazanin nedeni ile ilgili değerlendirmeler yaparak, çevreleri üzerinde kontrol elde etmeye çalışmaktadır. Bu atıflar kaza kurbanı, üst, ast olma gibi faktörlerin etkisinde yapılmaktadır. 
Kazanın nasıl oluştuğunu ortaya çıkarmak için iki temel model bulunmaktadır. İlk model, temel olarak kazanın doğrudan veya birincil nedenine ve özellikle kazaya neden olan kişi veya mekanizma hatalarına odaklanan geleneksel yaklaşımdır. Bu model, günümüzde büyük ölçüde gözden düşmüştür. İkinci model, daha detaylı bir yaklaşım kullanmakta ve doğrudan nedeni belirlemek gerektiği halde, kazanın kök nedenlerini araştırmaktadır (Whittingham,2008:215). Kök nedenlerin araştırılması, personel ile görüşmeler yapmayı içermektedir. Görüşmeler ve diğer bilgi toplama süreçlerinden sonra sorușturmacı kaza nedeni ile ilgili bir görüșe ulaşacaktır. Son olarak kaza ile ilgili bir rapor hazırlayarak ilgililere sunacaktır.

$\mathrm{Bu}$ nedenle iş kazalarının nedenleri ve yeniden olmalar1nın nasıl engelleneceği ile ilgili literatür, genel olarak kazaların nedensel açıklamalarından elde edilmiştir. Bu doğrultuda, iş güvenliği yönetimi ile ilgili faaliyetler önemli ölçüde işçilerin ve yöneticilerin kazalarla ilgili açılamalarına dayanmaktadır. Bundan dolayı atıf kuramı, iş güvenliği uygulamaları için büyük önem taş1maktadır. Çünkü bu değerlendirmeler, rasyonel bir biçimde yapılmayabilmekte, bir takım yanlılıklar ve çeşitli faktörlerden etkilenebilmektedir. Ayrıca kaza soruşturmaları sonucunda kazaların olası nedenleri ile işçilerin kaza atıflarının karş1laştırılması iş güvenliği açısından önem taşıyabilir. İşçilerin kazanın gerçek nedeninin farkına varıp varmadıkları belirlenmelidir.

Atıf kuramına göre iş kazaları, iki temel faktöre atfedilmektedir: İçsel faktörler (işçinin ruhsal ve kişisel özellikleri) ve dişsal faktörler (iş çevresi özellikleri). Literatürde, işçilerin genelde dişsal atıflarda ve yönetici- lerin de içsel atıflarda bulunduğu anlaşılmaktadır. İçsel ve dışsal atıfların işçi davranışları için farklı etkileri bulunmaktadır. Tablo 1'de, işçilerin iş kazalarına atfettikleri bazı içsel ve dişsal faktörler görülebilir. İş kazalarının nedeni için yapılan içsel atıflar vasıf eksikliği, kibir, gösteriş yapma ve kavrama eksikliği gibi kişiye özgü faktörlere işaret etmektedir. Diğer yandan dişsal faktörler düşük ücret, fazla iş yükü, yetersiz eğitim gibi örgütsel faktörlerden uğursuzluk ve dini inanç gibi faktörlere kadar farklılık göstermektedir.

Tablo 1

Dişsal ve İçsel Faktörler

\begin{tabular}{|c|c|}
\hline Dışsal Faktörler & İçsel Faktörler \\
\hline Düşük ücretler & Vasıf eksikliği \\
\hline Zaman tasarrufu & Profesyonel kibir \\
\hline Fazla iş yükü & Dikkat kaybı \\
\hline Arızalı ekipman & Yanlış anlaşılma \\
\hline Yetersiz eğitim & Kötüye kullanma \\
\hline Yönetim baskısı & Yeterli kavrama yeteneği eksikliği \\
\hline Çalışma arkadaşlarının hataları & Riskli iş davranışı \\
\hline Konsantrasyon kaybı & Tecrübesizlik \\
\hline Operasyonel prosedürler & Dikkatsizlik \\
\hline Yanlış görevlendirme & Gösteriş yapmak \\
\hline Uğursuzluk & Önemsememek \\
\hline Dini inanç & Iş güvencesi hissi \\
\hline Kötü yönetim & Ruh hali, kötü bir gün geçirme \\
\hline Görev zorluğu ve belirsizliği & Kasıtlı ihmal \\
\hline
\end{tabular}

Kaynak: Gyekye,2010:408.

Kelley'in gözlemcinin aktörün davran1şını izlerken kullandığ lik ve konsensüs ölçütleri, iş güvenliği ile ilgili davranışların değerlendirilmesinde de geçerlilik taşımaktadır. Örneğin bir yönetici, güvenlik kurallarını ihlal eden bir işçiyi izleyebilir. Yönetici tutarlılık, ayırtedicilik ve konsensüs bilgisine dayalı olarak işçinin güvenlik kuralını neden ihlal ettiği ile ilgili farklı atıflarda bulunabilir. Yönetici işçi dav- 
ranışını üç temel nedene atfedilebilecektir: işçi (aktör-davranışı gerçekleştiren kişi), görev (kendilik-davranışın neye yöneltildiği) veya durum (ortam-davranışın oluştuğu koşullar). Glendan vd. (2006), bu üç atıf biçimini bu üç ölçüte göre şöyle örneklemişlerdir:

\section{Senaryo A:}

1. Yüksek konsensüs: Aynı durumda tüm işçiler bu güvenlik kuralını ihlal edebilirdi.

2. Yüksek ayırtedicilik: Bu işçi sadece belirli bir durumda güvenlik kuralını ihlal eder, fakat genel olarak güvenlik kurallarını ihlal etmez.

3. Düşük tutarlılık: Bu işçi aynı durumda bu kuralı her zaman ihlal etmez.

Nedensel atfetme: Durum-belirli bir durum kurala uyulmasını imkansız kılmaktadır.

\section{Senaryo B:}

1. Yüksek konsensüs: Aynı durumda tüm işçiler bu güvenlik kuralını ihlal edebilirdi.

2. Yüksek ayırtedicilik: Bu işçi sadece belirli durumda güvenlik kuralını ihlal eder, fakat genel olarak güvenlik kurallarını ihlal etmez.

3. Yüksek tutarlılık: Aynı işçi aynı durumda bu kuralı her zaman ihlal eder.

Nedensel atfetme: Kendilik-Bu belirli durumda güvenlik düzenlemesi işlememektedir.

\section{Senaryo C:}

1. Düşük konsensüs: Diğer işçiler aynı durumda bu güvenlik kuralını ihlal etmezlerdi.

2. Düşük ayırtedicilik: Aynı işçi diğer durumlarda da genel olarak güvenlik kurallarinı ihlal eder.

3. Yüksek tutarlılık: Aynı işçi bu güvenlik kuralını aynı durumda her zaman ihlal eder.

Nedensel atıf: Aktör-işçi bu iş için uygun değildir, örneğin kendine fazla güven duyma, kibirli veya risk alan veya güvenliğge karşı kibirli bir tutumu vardır.

Üç nedensel atfetme biçimi, bu davranışın tekrar etmemesi açısından yöneticileri farklı uygulamalara yönlendirmektedir. Senaryo $\mathrm{A}^{\prime} \mathrm{da}$, işyerinin mevcut güvenlik iklimi ve üst davranışlarını hedefleyen kültürel bir müdahaleye ihtiyaç duyulabilir. Senaryo B'de, işçilere danışarak görevle ilgili kuralların ve prosedürlerin gözden geçirilmesi şeklinde iş görevini hedefleyen bir müdahaleye gerek olabilir. Senaryo $C^{\prime}$ de ise, davranışın algılanan içsel nedeni örneğin kisilik veya tutumlar veya davranışın kendisini hedefleyen bireysel düzeyde bir müdahaleye ihtiyaç duyulabilir (Glendan ve diğ.,2006:86).

Davranışın kendisini hedefleyen müdahalede durumunda, yönetici ceza aracil1ğıyla davranış değiştirmeyi veya güvenliğe karşı tutumları geliştirmeyi deneyebilir. Bununla birlikte, davranışın nedeni kişilik gibi sabit ve içsel ise, işten çıkarma önerilebilir. Ayrıca kötü güvenlik performansı, güvenlik kurallarına uymamak gibi kontrol edilebilir faktörlere atfediliyorsa, sıklıkla ağır ve cezalandırıcı faaliyetlere başvurulur (Glendan ve diğ.,2006:86). Bu değerlendirmelerden anlaşılacağ1 üzere, iş güvenliği ile ilgili işçi davranışlarına atfedilen faktörler, işletmenin güvenlik faaliyetlerini etkilemektedir. Ancak literatürde bu atıfları etkileyebilecek çok sayıda faktörden söz edilmektedir. Bu bölümde çeşitli faktörlerin atıflar üzerindeki etkileri incelenecektir.

\section{Demografik Özelliklerin Atıflara Etkisi}

Yaş, bireylerin yaptıkları değerlendirmeleri etkileyen önemli bir değişkendir. Yaşı performans değerlendirme açısından ele alan Liden vd.'nin (1996) araştırmasında, üstlerin ve işçilerin yaşlarının nitel ve nicel performans değerlendirme sonuçları üzerinde etkili olduğu tespit edilmiştir. Yaş benzer şekilde, işçilerin iş kazalarını atfettikleri nedensel faktörleri etkilemektedir. Kaza nedenleri konusunda yaşlı işçilerin gençlere göre daha fazla dişsal faktörlere atıfta bulundukları belirtilmektedir. Örneğin Niza 
vd. (2008) araştırmasında yaşlı işçilerin iş kazalarını beklenmedik ve dış kaynaklı gördükleri, genç işçilerin ise daha çok örgütsel faktörleri sorumlu tuttukları belirlenmiștir. İş tecrübesi nedensel atıflar açısından yaş ile benzer özellik göstermektedir. Tecrübeli işçiler ve üstler, sorumluluğu dişsal faktörlere atfederken, tecrübesi düşük olanlar içsel faktörlere yönelmektedir.

Cinsiyetin iş güvenliği ile ilgili nedensel atıflara etkisini inceleyen yeterli araştırma bulunmadığı görülmektedir. Ayrıca bazı araştırmalarda nedensel atıfların cinsiyete göre başka değişkenlerle ilişkili olarak farklılık gösterebildiği belirtilmektedir. Örneğin Kouabenan vd.'nin (2001) araştırmasında, cinsiyetin sadece hiyerarşik pozisyon ile ilişkili olarak nedensel atıfları etkilediği tespit edilmiştir. Buna göre erkek üstler, bir kazayı erkek astlara göre daha fazla oranda kurbana atfetme eğiliminde iken, değişik hiyerarşik pozisyonlardaki kadınlarda ise nedensel atfetme açısından farklılık bulunmamaktadir.

\section{Bireysel Durumların Atıflara Etkisi}

\section{İş Doyumu}

İş doyumunun yüksek olması, örgütün işçilerin temel ihtiyaçlarını karşılayabildiği anlamına gelmektedir. Ayrıca işçilerin örgütün desteğini hissetmeleri, kendilerini değerli ve güvende görmelerini sağlayacaktır. $\mathrm{Bu}$ algilamalar, güvenlik iklimi ile ilgili olumlu düşüncelere neden olacaktır
(Gyekye,2005:292). İş doyumu düzeyinin, iş kazalarının nedensel atıfları üzerindeki etkisini inceleyen bir araştırmada, iş doyumu düşük olan işçilerin iş doyumu yüksek olanlara göre, iş kazalarını daha fazla dişsal faktörlere atfettikleri ve göreceli olarak daha fazla iş kazasına karıştıkları belirlenmiştir (Gyekye,2010:408). Kısaca, iş doyumu yüksek olan işçilerin iş kazalarının nedenlerini içsel faktörlere yükleme eğiliminde oldukları söylenebilir. Ayrıca iş doyumu düşük olan işçilerin daha fazla iş kazasına karışmaları dikkat çekicidir.

\section{İş Kazası Tecrübesi}

Gonçalves vd.'nin (2008) bir sanayi işletmesi ile bir araştırma geliştirme işletmesinde yaptıkları araştırma, iş kazası tecrübesinin içsel ve dışsal atıfları ve ayrıca atıfların aracı değişken olarak risk ve güvenlik boyutlu iş davranışlarını nasıl etkilediğini incelemektedir (Şekil 2). Araştırma bulgularında, iş kazası tecrübesinin dişsal atıflar ve güvensiz davranışlarla pozitif; içsel atıflarla negatif ilişkili olduğu tespit edilmiştir. İşçiler kaza tecrübesinin nedenini savunmacı bir tutumla dişsal nedenlere atfetmekte ve dişsal nedenler ise güvensiz davranışları arttırmaktadir.

Bu durumda iş kazası geçiren işçilere yönelik olarak, kazanın nedenleri açısından bir değerlendirme yapmaları istenerek, işçiye göre kaza nedeni ile kaza soruşturması sonucu ulaşılan kaza nedeni karşılaştırılmal1dır. Kaza nedenleri arasında farklılık olduğu

\section{Şekil 2}

\section{İş Davranışı ve Nedensel Atıf Modeli}

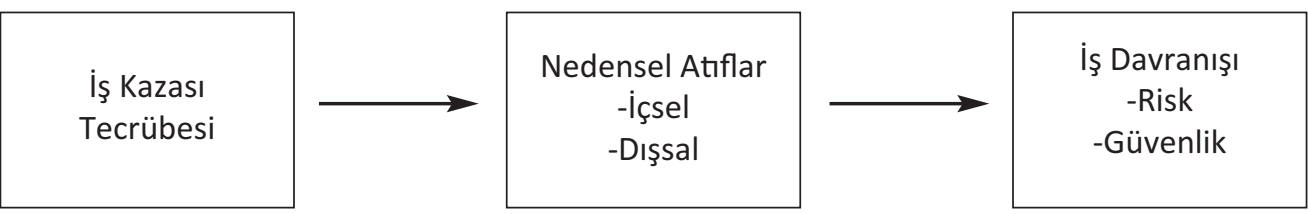

Kaynak: Goncalves,2008:994. 
anlaşılırsa, bunun giderilmesi için çalışılmalıdır. Çünkü iş kazası nedenini dışsal faktörlere atfeden işçi, güvensiz davranışlara devam edebilecektir. Ancak Demirbilek ve Çakır (2008), 430 işçiden oluşan bir örneklemde, iş kazasına yönelik neden atfetmenin güvenli bir davranış olan kişisel koruyucu donanım kullanımında etkili olmadığını tespit etmiştir. İş kazası neden atıfları ile güvenli davranış arasındaki ilişkinin belirlenmesi için başka araştırmalara gerek duyulmaktadır.

\section{Çalışma Arkadaşları}

Gyekye (2006), bir iş kazasını gören ve maruz kalan üç işçi grubunu araştırmıştır. $\mathrm{Bu}$ işçiler iş kazası kurbanları, kazayı gören iş arkadaşları ve üstlerdir. Bu işçi grupları ayrıca üç açıdan farklılaşmaktadır: durumla bağlantılı (kaza kurbanı ile benzer fiziksel koşulları algılayanlar, benzer araçları ve makinaları kullanan iş arkadaşları); kişiyle bağlantılı (kişisel özellikler, değerler ve inançlarda benzerlik algılayan iş arkadaşları) ve son grup olarak herhangi bir bağlantı algılamayan iş arkadaşları belirlenmiştir. Buna göre, durum ve kişi bağlantılı olan iş arkadaşları daha çok iş ve çevresel faktörlere (dişsal faktörlere) atıfta bulunurken, kaza kurbanına daha az sorumluluk yüklemekte ve onları temize çıkarmaktadır. Bağlantı algılamayan iş arkadaşları ise daha fazla içsel atıfta bulunmakta ve iş kazası kurbanına daha fazla sorumluluk yüklemektedirler. Böylece, kazayı gören iş arkadaşlarının hangi durumlarda kaza nedenlerini kurbana atfettikleri anlaşılmaktadır. Durum ve kişi bağlantılı iş arkadaşları benzer bir kazanın kendi başlarına da gelebileceğini düşünürek, kaza nedenini dişsal faktörlere bağlamaktadır. Bağlantı algılamayan iş arkadaşları ise, aktörün yani kurbanın başına geleni hakettiğini vurgulayan "adil dünya inanc1" kuramı çerçevesinde değerlendirme yapmaktadır. Çalışma arkadaşları ile birlikte değerlendirilebilecek başka bir grup işletmedeki uzmanlardır. Uzmanlar, riskler ve nedensel açıklamalarda yanlı olma ile kendi aralarında uzlaşmazlık yaşama eğilimi gös- termektedirler. $\mathrm{Bu}$ yanlıliklar sadece uzmanların tecrübe ve eğitimlerinden değil, olaydaki belirsizliklerden kaynaklanabilmektedir (Gyekye,2010,s.409).

\section{Örgütsel Özelliklerin Atıflara Etkisi}

Nedensel atıflar sadece demografik ve kişisel özelliklerden etkilenmemektedir. Örgüt büyüklüğü, meslek düzeyleri gibi birtakım örgütsel özellikler de atıflarda önem taş1maktadır. Öncelikle örgütteki güvenlik iklimi nedensel atıflar için önemli bir faktördür. Güvenlik iklimi, işçilerin iş çevresinin güvenliği hakkında paylaştıkları alg1lara işaret etmekte ve gerçekleştirilen günlük görevlere karşı bir temel sağlamaktadır. Paylaşılan algılar yönetim kararları, örgütsel güvenlik normları ve beklentileri, güvenlik uygulamaları, politikaları ve prosedürlerini kapsayan, güvenliğe örgütsel bağlılığı gösteren farklı faktörlerden kaynaklanmaktadır. Güçlü güvenlik iklimi olan örgütlerde, iş kazaları daha az gerçekleşmektedir (Hahn ve Murphy, 2008:1048). Bu örgütlerde işçiler, iş güvenliği konusunda daha bilgili oldukları için, iş kazalarını daha karmaşık bir yaklaşımla içsel ve dişsal faktörleri birleştirerek yorumlamakta ve açıklamaktadır. Bu durumda örgütün güvenlik iklimi, işçilerin nedensel atıflarında ara değişken olarak değerlendirilmelidir (Gyekye,2010:411).

Güvenlik iletişimi, atıfları etkileyen diğer bir örgütsel değişken olarak değerlendirilebilir. Hoffmann ve Stetzer (1998), farklı senaryoların uygulandığı işçi gruplarında, güvenlik iletişiminin iş kazalarını nedenlerinin yorumlanmasına etkilerini araştırmışlardır. Güvenlik konularının açıkça tartışıldığ 1 gruplarda, işçilerin senaryoda verilen ipuçları (içsel veya dışsal) ile tutarlı atıflar yapmaya eğilimli oldukları bulunmuştur. Güvenlik iletişiminin açık olmadığı gruplarda ise, senaryo bilgisi tam tersi atıfları gerektirdiği halde, işçilerin dışsal faktörlere atıfta bulunma eğiliminde oldukları tespit edilmiştir. Araştırmada ayrıca güvenlik iklimi de incelenmektedir. Görüldügüü üzere, güvenlik iklimi ve etkilediği diğer değişken- 
ler, iş kazalarının nedensel açıklamalarını etkilemektedir.

Örgüt büyüklüğü, işletme sahibinin iş kazalarına bakışı açısından değerlendirilebilir. Küçük işletmelerde iş kazaları daha fazla yaşanmakta ve önleyici tedbirlerin alınması için kaynak sıkıntısı bulunmaktadır. Ayrıca küçük işletmelerde güvenlik ile ilgili yazılı belgeler çok önem taşımamakta ve bir kaza sonrası işletme sahibinin yaklaşımı risklere karşı tutumunu göstermektedir. Küçük işletme sahipleri iş kazalarını öngörülemeyen koşullara, diğer bir deyişle, kötü şansa bağlamaktadır. Bu şekilde kendi kontrolleri altında olan faktörlerin iş kazasına yol açtığını reddetmektedirler. Bu durumda, is kazalarından örgütsel öğrenme çok az gerçekleşmekte, kaza geçiren işçi genellikle aynı güvensiz koşullarda çalışmaya devam etmektedir (Hasle ve diğ.,2009:10-17). Ayrıca işletme sahibi ile işçiler arasındaki yakın ilişki, işçilerin kaza için suçlanmasını sınırlandırmaktadır. Dolayısıyla bu faktörün de güvenlik uygulamalarını olumsuz etkilediğ $i$ ve büyük işletmelere göre daha yüksek kaza oranları ile karşılaşılmasına neden olduğu ileri sürülmektedir.

Son olarak, meslek farklılıklarının nedensel atfetme üzerindeki etkisine değinilmelidir. İş kazası oranları mesleklere göre önemli farklılıklar göstermektedir. Bu durumda iş kazası ile ilgili nedensel atıflarda da farkl1lıklar olması beklenebilir. Gyekye'nin iş kazası geçirmiş maden ve tekstil işçilerinden elde ettiği araştırma bulgularına göre, meslek üyeleri arasında nedensel atfetme açısından anlamlı bir farklılık bulunmamıştır (Gyekye,2006:533). Çalışma koşulları açısından önemli farklılıklar olan işlerde çalışan işçilerin atıf farklılıklarının olmaması dikkat çekicidir. Ancak başka bir araştırmada, mühendisler ile yöneticiler arasında iş kazaları açısından atıf farklılıkları olduğu tespit edilmiştir.

Gherardi vd. (1998), bir inşaat işinde çalışan mühendisler ile şantiye yöneticilerinin gördükleri veya kendilerine anlatılan iş kazalarını nelere atfettiklerini incelemişlerdir.
Mühendisler doğrusal ve mantıklı açıklamalar yapmakta ve örgütten kaynaklanan sistemik nedenleri vurgulamaktadır. Örneğin mühendisler, sıklıkla şunları dile getirmektedir: işgücünde güvenlik kültürü eksikliği, güvenlik için yetersiz örgüt ilgisi ve kaza önleme faaliyetlerinin işletmeye olan yüksek maliyeti. Mühendislerin nedenlendirme modeli, kazaların gizli ve birincil nedenlerini arasında ayrımlaşmakta ve bu ayrımlaşmayı genelleştirerek olaylara deterministik algılamayı uyarlamaktadır. Ayrıca sorunları soyut terimlerle (örneğin insan hatası, ekonomik faktörler vb.) kavramlaştırma eğilimi taşımakta ve iş kazaları ile riskli durumlara nadiren somut açılamalar getirmektedir.

Diğer yandan yöneticilerin açıklamaları, çok boyutlu faktörlerin vurgulandığı bir nedensel model kullanmaktadir. Bu model güncel kazalara referanslar ile sıkı bir dikkatin gösterildiği, somut bir fenomendir. Buna ek olarak, kaza nedenleri ortaya konmakta, önemleri ve güvenliğe etkileri açısından sıralanmaktadır. Yöneticilerin olayları algılamalarının temelinde, olayların birbiri ile ilişkili olduğu ve eşzamanlılığı hissi bulunmaktadır. Bu mantığın sonucu olarak, yöneticiler her kazayı kendi içinde bir fenomen olarak görme, özel ve detaylı bir tanım yapma eğilimindedir. Örneğin güvensiz bir iş ortamı soyut olarak tanımlanmamakta, örneklerle donatılmakta ve kazaların birincil nedenleri vurgulanmaktadır (Gherardi,1998:207).

\section{Atıfları Etkileyen Diğer Faktörler}

\section{Din}

Din nedensel atıfları etkileyebilecek önemli bir değişken olarak görüldügüu halde, iş kazalarının nedensel atıfları ve dini inanç üzerine yeterli araştırmanın yapılmadığ 1 söylenebilir. Gyekye ve Salminen (2007), Ganalı bir örneklemde üç ayrı dini inanç grubu için iş kazalarının nedensel atıflarını incelemişlerdir. Bu üç inanç grubu hristiyan, müslüman ve geleneksel Afrika dinine inananlar olarak belirlenmiştir. Araştırma bulgularına 
göre, müslümanlar ve geleneksel Afrika dinine inananlar kaza sürecinde, hristiyanlara göre daha fazla oranda doğaüstü ve sihirsel etkileri vurgulamaktadır. Müslümanlar ve geleneksel Afrika dinine inananlar, kazaların kaçınılmaz ve insan kontrolünün ötesinde olduğunu yansitan dişsal ve durumsal atıflar belirtmektedir. Örneklem zaman içerisinde izlendiğinde Müslümanlar ve geleneksel Afrika dinine inananlar arasında risk alma davranışı ve kaza sıklığının arttığı belirlenmiştir. (aktaran Gyekye,2010:409).

\section{Kültür}

Kültür, iş kazalarının nedenleri ile ilgili atıflarda farklılaşmaya neden olabilecek bir faktördür. Araştırma bulguları, atıf süreçlerinin toplulukçu ve bireyci kültürlerde farklılaştığını göstermektedir. Bireyci kültürlerde, bireyler içgruplarından duygusal olarak kopukturlar; ayrışıklık ve özerklik gereksinimi büyüktür. Onlar için kişisel amaçlar, grup amaçlarından önce gelir; davranışlar yarar-zarar analizi çerçevesinde incelenir ve başkalarıyla çatışma olağandır. Toplulukçu kültürlerde ise, kişinin benliği içgrup terimleriyle tanımlanır. Bireyler için grup amaçları bireysel amaçların önüne çıkar ve kişinin davranışları içgrubun istekleri ve normları doğrultusunda belirlenir (Kağıtçıbaşı,2004:360). Bu durumda, kültürler arasında nedensel atıfların farklı olması doğal kabul edilmelidir.

Havold (2007), Norveç deniz taşımacılığ1 firmalarında çalışan 27 ülke vatandaşından oluşan 2558 kişilik örnekleminde, güvenlik yönelimi modeline ulusal kültürün dahil edilebileceğini ve güvenlik faktörlerinde ulusal ve bölgesel kültürler arasında önemli farklılık olduğunu tespit etmiştir. Ayrıca Gyekye (2001), Finli ve Ganalı işçiler üzerinde yaptığ 1 araştırmasında, Finli işçilerin daha çok içsel ve ruhsal faktörlere ve daha az oranda çevresel faktörlere atıfta bulunduklarını tespit etmiştir. Bu arada, toplulukçu kültür yönelimli Ganalı işçiler, daha fazla çevresel ve ortamsal faktörlere ve daha az ruhsal faktörlere atıfta bulunmaktadır (aktaran Gyekye,2010:410). Bu açıklamalardan, kültürün iş kazaları ile nedensel atıfları etkileyen önemli bir değişken olduğu ileri sürülebilir.

\section{Atıf Sürecinde Hatalar ve Yanlılıklar}

\section{Temel Atıf Hatası}

Temel atıf hatası, içsel atıfla aynı şeydir. Hata olarak ele alınmasının sebebi, içsel atıf yapma eğiliminin, durumsal koşulları gözardı etmeye ve bunun sonucu yanlış çıkarsamalara yol açabilmesidir. İnsanlar davranışların nedeni içinde bulunulan koşullarda yatma olasılığında bile, olayı kişisel özelliklere dayanarak açıklamaya meyillidir (Kağıtçıbaşı,2004:237). Bir başka deyişle, olayların nedeni olarak koşullara değil, kişilere odaklanılmaktadır. Örneğin davranışı gözlenen kişinin özgür olup olmadığına, tercih imkanının bulunup bulunmadığına bakılmaksızın, kişisel özellikleri ön plana çıkarılmaktadır. Bireyin, bir başkasının davranışını açıklama çabasında, durum ne olursa olsun, diş etkenlerin aleyhine iç etkenlerin rolüne ağırlık verme eğilimi, temel atıf hatası olarak tanımlanmıştır (Bilgin,2003:383).

Temel atıf hatası, iş güvenliği ile ilgili konularda yöneticilerin ve üstlerin, durumsal faktörlere göre işçi ile ilgili faktörlerin üzerinde daha fazla durmaları şeklinde ortaya çıkmaktadır. Bu yanlılık sonucu, Perrow kaza soruşturmacılarının \%60-\%80 oranında olayı işçilere atfettikleri, ancak daha detaylı analizler sonucunda olayların \%30-40'ında bu durumun doğru olduğunu belirlemiştir. Diğer yandan işçiler de, kazaları tasarım hataları veya kontrol düzenlemelerine atfetmektedirler. İş kazalarını önlemeye yönelik uygulamalar ise, genelde kişilerin davranışlarının değișmesi ile ilişkilidir ve bundan dolayı kaza raporlarından çıkan sonuç "işçinin bu davranışı tekrar yapmaması" için uyarılmasıdır. Fakat kaza ile ilgili olarak kendilerini sorumlu görmeyen işçilerin, bu tip uyarılara karşı direnç gösterdikleri belirtilmektedir (Glendan ve diğ.,2006:88). 


\section{Aktör-Gözlemci Etkisi}

Davranışı seyreden gözlemci davranışın sebebini aktörün kişilik özelliklerine bağlayarak, içsel atıfta bulunur ve temel atıf hatasına düşer. Davranışı yapan aktör ise, yaptığı davranışın sebebini ortamın etkilerine bağlayarak dişsal atıfta bulunur (Arkonaç,2005:146). Aktör ve gözlemci arası farklılık çeşitli nedenlere bağlanabilir. Örneğin atıf için sahip olunan verilerin farklılı̆̆ 1 , aktörün kendi hakkında gözlemciden daha fazla detay bilgi sahibi olması, çeşitli verilere verdikleri önemin aynı olmaması bu konuda etkili olabilir. Ayrıca bilgi-işlem tarzları da aynı değildir. Zira, gözlemci davranışın içinde yer aldığı bağlama değil, bizzat davranışa odaklaşır, aktörü aynı bağlamda bulunan diğer aktörler ile karşılaştırır, dolayısıyla aktörün temel eğilimlerini, kişisel özelliklerini değerlendirme konumundadır. Oysa aktör, kendi davranışını, diğgerlerinin davranışlarına göre değil, kendisinin başka bağlamlardaki diğer davranışlarına göre değerlendirme konumundadır (Bilgin,2003:21). Demirbilek (2005) tekstil sektöründe faaliyet gösteren bir işletmede yaptığı araştırmada, işçi ve yönetim algılaması ile iş kazası nedeni değişkeni arasında anlamlı bir farklılık olduğunu tespit etmiştir. Kısaca, ișçi ve yöneticilerin iş kazalarını farklı nedenlere atfettikleri anlaşılmaktadır.

Aktör-gözlemci etkisi, üstler ve kaza kurbanlarının iş kazası ile ilgili nedensel atıf farklılıkları için kuramsal açıklamalar sunmaktadır. Üstler, astlarla ilgili içsel faktörlere daha fazla atıfta bulunurken, astlar da daha fazla oranda dışsal faktörlere atıfta bulunma eğilimindedir. Yukarıda belirtildiği gibi, bu farklılığa çeşitli faktörlerin neden olduğu ileri sürülmektedir. İlk faktör, üstler ile kaza kurbanları arasındaki bilgi düzeyi farklılığıdır. Kaza kurbanları kendi iş davranışları ve değişkenliği konusunda üstlere göre daha fazla bilgi sahibidir. İkinci olarak, dikkat ve görsel yönelim farklılıkları açıklamalarda kullanılmaktadır. Astlar (aktör) için, çevre sürekli değişken ve dinamik iken, kendi davranışlarında sabitlik göstermektedir. Üst (gözlemci) için, işçinin (aktörün) davranışı değişken, çevre ise sabit bir ögedir. Üst için işçinin davranışı odak noktasındadır. Üçüncü faktör ise, motivasyonel faktörlerle ilişkilidir. Özsaygıyı ve iş pozisyonunu korumak gibi motivasyonel istekler, astların dışsal atıflarda ve üstlerinde işçi ile ilgili içsel atıflarda bulunmalarına neden olabilmektedir (Gyekye,2010:412).

Aktör-gözlemci etkisinden iş güvenliği eğitimlerinde yararlanmak mümkündür. McSween (2003), bir deney ile aktör-gözlemci etkisinin iş güvenliği üzerindeki olası yararını ortaya koymuştur. İki gruba ayırdığı işçilerden çeşitli işleri yapmaları beklenmiş ve daha sonra işçilere bu işlerin nasıl güvenli şekilde yapılacağı açıklanmıştır. Ayrıca işçiler diğer bir işçi grubunu izleyerek, güvenlik standartlarına uygunluğu değerlendirmiş ve kontrol listeleri doldurmuşlardır. Sonuç olarak, bu deney aktör-gözlemci etkisini göstermekte, izleme sonucunda işçilerin işlerini daha güvenli yapabildiklerine dikkat çekmektedir. Böylece, yapılan işlerin kaydedilerek tekrar izlenmesi iş güvenliğ $i$ eğitimlerinde kullanılabilecek bir uygulama olarak görülmektedir.

\section{Benliğe Hizmet Eden Yanlılıklar}

Yapılan işlerde gösterilen başarı veya başarısızlığa yüklenen sebepler birbirinden farklılaşmakta, biri benliği desteklerken diğeri benliği kayırıcı nitelik taşımaktadır. Başarılarımızın sebebini, ne kadar yetenekli olduğumuza, çok çalışmamıza dayandırarak açıllarız. Başarısız olduğumuzda durumlarda ise sebepleri ortamda, durumda ararız, işin zorluğu, şansızlık, haksızlık gibi sebepler yükleriz. Başarısızlık karşısında dişsal atıflar yaparak benliği korumuş oluruz (Arkonaç,2005:149). Bu duruma her kültürde rastlanabilmektedir ve iş güvenliği açısından önem taşımaktadır.

Kişiler, istenmeden meydana gelen zararlar veya kazalar için suçlanmayı istememektedir. Özellikle, kazasız geçen toplam gün sayısı gibi hedefleri vurgulayan işletmelerde, işçiler bir iş kazası için sorumlu tutulmaktan kaçınmaktadır. Ayrıca, kaza soruşturması adı verilen süreçlerin de işçi- 
leri benliğe hizmet eden yanlılıklara yönlendirebileceği ileri sürülmektedir. Bu soruşturmalara, bir suçlu arandığını vurgulamayan olay analizi gibi isimler verilmesinin daha doğru olabileceği belirtilmektedir. Bununla birlikte örgüt kültürünün, kaza kurbanının olaya durumsal veya dişsal faktörlerin neden olduğunu vurgulamasinı desteklemesi ve kurbanın kendini daha rahat hissetmesi sayesinde davranış gibi gözlemlenebilir faktörlere odaklanılabileceği de ileri sürülmektedir (Geller,2001:105).

Soruşturma sürecinde, kazanın insan hatasından kaynaklandığı belirlenirse, yönetim işçiyi suçlu atfedecektir. Bu durumun iş güvenliği açısından iki önemli sonucu olabilir. Öncelikle, suç atıfı hatanın esas nedenin göz ardı edilmesine yol açacaktır. Suç atıfları, insan hatalarının yüksek bir oranda üretim araçları veya yazılı prosedürler gibi fiziksel sistemler, işletme yapısı, güvenlik kültürü veya yönetim sistemi gibi fiziksel olmayan sistemlerden kaynaklandığını dikkate almamaktadır (Whittingham,2008:230).

İkinci olarak, suçlu atfetme hataların rapor edilmesini engelleyebilecektir. İşçilerin hataları nedeniyle suçlandığ 1 ve cezalandırıldı̆̆ 1 bir örgütte, kazalara yol açmayan hatalar rapor edilmeyecektir. Heinrich piramidi, her kazanın insan hatalarını da kapsayan bir kazaya neden olmayan çok sayıda öncülü olduğunu göstermektedir. Bu nedenle, sadece kazaya neden olan hataların dikkate alınması, iş güvenliği faaliyetlerine zarar verecektir (Whittingham,2008:230).

Bir başka yanlılık ise, kişilerin bir olayın sonuçlarının ciddi olması durumunda, önemsiz olmasina göre daha fazla sorumlu tutulmasidir. Bu durumda, "kil payı kurtulma" gibi kişilere fazla zarar vermeyen, ancak zarar verme potansiyeli taşıyan olaylarda, kişilere sorumluluk yüklenmemektedir (Lingard ve Rowlinson,2005:239). Bu yanlılık, ciddi sonuçların bir şekilde kontrol edilebilir ve dolayısıyla önlenebilir olduğu varsayımından kaynaklanmaktadır. Örneğin, ciddi sonuçları olan bir olaya karışan ki- şinin, bu sonuçları öngörebilmesi ve ortaya çıkmasını önlemek üzere sorumlu olması beklenmektedir (Glendan ve diğ.,2006:89).

\section{Nedensel Atıfların İş Kazası Sonrası Etkileri}

Literatürde dikkat çeken araştırma konularından birisi de, işçilerin iş kazalarına iliş̧kin nedensel atıflarının kaza sonrasında işe dönme sürecini nasıl etkilediğidir. Brewin (1984), iş kazası geçiren erkek işçilerle, kazadan hemen sonra ve rehabilitasyon süreci bittikten sonra iş kazalarının nedensel atıflarının rehabilitasyon sonucunu nasıl etkilediğini anlamak için görüşmeler yapmıştır. İş kazasından kendilerini sorumlu gören kurbanlar, psikolojik sağlıkları daha iyi olmadığ 1 halde, ișe döndüklerinde ruh hallerinin daha iyi olduğunu belirtmişlerdir. Ayrıca, kendini kusurlu gören işçilerin işlerine daha çabuk döndükleri ortaya çıkmıştır. İş arkadaşları veya işverenlerin suçlamaları ile rehabilitasyon sonuçları arasında bir ilişki tespit edilmemiştir.

Rush vd. (2003) ise, el ile ilgili bir travma sonrası ișe dönme sürecini nedensel atfetme kuramından faydalanarak araştırmıştır. İş kazası sonucunda el yaralanması yaşayan 92 işçi, kazanın kendilerine göre nedeni konusunda değerlendirilmiştir. Kaza için çalışma arkadaşlarını veya ekipmanı suçlayan işçiler, kaza nedeniyle kendilerini sorumlu gören işçilere göre, önceki iş faaliyetlerine dönmeyi reddetmeye daha isteklidirler. $\mathrm{Bu}$ açıklamalardan da anlaşılacağ zasının nedenlerine yapılan atıfların ișe dönme ve rehabilitasyon süreci üzerinde etkisi bulunmaktadır. Sebeplerin kalıcılığ 1 ve geçiciliği ile kontrol edilebilirliği, işçi açısından işe dönme süreci ve benzeri birçok süreci etkileyebilecektir. Bu noktadan yola çıkarak, iş kazasına yapılan atıfların işçilerin iş doyumu, örgütsel bağlılık, iyilik hali vb. gibi kavramlar üzerindeki etkisinin araştırılması önerilebilir.

\section{Sonuç}

Psikolojik kuramlar, iş sağlığı ve güven- 
liği alanında giderek daha fazla önem kazanmaktadır. İşçinin davranışlarının nasıl şekillendiği ile yöneticiler ve uzmanların bu davranışları nasıl değerlendirdikleri konusunda psikolojik kuramlar, özellikle de atıf kuramı, önemli katkı sağlayabilmektedir. İş kazaları ile ilgili incelemeler kazaların nedenlerini ortaya çıkarmakta, ancak işçiler, yöneticiler, uzmanlar ve soruşturmacıların kaza nedenleri konusunda farklı görüşleri olabilmektedir.

Örneğin kaza kurbanı işçi sorumlu tutulmamak için kazayı kendi dışındaki nedenlere atfederken, çalışma arkadaşları da benzer şekilde arkadaşlarını korumak ve aynı şeyin kendi başlarına gelebileceğini düşünürek dişsal nedenlere atıflarda bulunmaktadır. Diğer yandan güvenlik uzmanları, kazanın yetersiz eğitim gibi nedenlere bağlanmaması için iş̧̧i ile ilgili faktörlere yönelebilmekte, yönetici ise maliyetleri arttırmamak için uygun olmayan donanım gibi faktörlerden ziyade işçi ile ilgili faktörlere odaklanabilmektedir. Soruşturmacılar ise, bu görüşleri değerlendirerek yanlış kararlar alabilmektedir. Dolayısıyla kaza soruşturmacıları için işçi, yönetici ve uzman görüşlerini dikkatle değerlendirmek gereklidir.

İşçi, yönetici ve uzman gibi sosyal kategorilerin farklı nedenlere atıflarda bulunmalarının yanısıra, yaş, iş doyumu, iş kazası tecrübesi gibi bir takım faktörler de işçilerin kaza nedenleri ile ilgili atıflarını etkilemektedir. Bu faktörler yaş, iş kazası tecrübesi gibi bireysel olabilirken, güvenlik iklimi ve örgüt büyüklüğü gibi örgüte özgü ve hatta bunun ötesinde, dini inanç ve kültür gibi faktörler de olabilmektedir. Yönetici ve kaza soruşturmacılar, iş kazalarını araştırırken bu gibi faktörleri göz ardı etmeden değerlendirme yapmalıdir.

İş kazaları ile ilgili nedensel atıflar, kişiye özgü bir takım faktörlere veya kişidışı faktörlere yapılabilmektedir. Bu atıflar ile ilgili önemli bir konu, iş kazası nedenini dışsal bir faktöre yükleyen işçinin, nedeni kendisine yükleyen ve bu doğrultuda önlem alan bir değerlendirme karşısında direnç göstermesidir. Bu durumda, işçinin alınan iş sağlığ 1 ve güvenliği önlemlerine düzgün bir şekilde uyması beklenmeyebilecektir. Örgütlerde iş kazalarının incelenmesi sürecine farklı adlar verilmesi, işçilerin kaza nedenlerini rahatça açıklayabilecekleri kültürün yaratılması faydalı olacaktır. Aksi takdirde suçlanmaktan korkan işçiler, iş kazalarını rapor etmekten kaçınabilecektir.

İş kazaları açısından diğer önemli bir nokta ise kaza geçiren işçinin yaptığı atıflar ve işe dönme durumudur. Araştırmalar, iş kazasını içsel ve dışsal bir nedene yüklemenin işçinin işe devam etmesi ile ilişkili olduğunu göstermektedir. Örneğin iş kazası için çalışma arkadaşlarını veya ekipmanı suçlayan işçinin, işine dönme eğilimi daha fazladır. Ancak bu süreç için daha kapsamlı bir incelemeler yapılması gereklidir. "İş kazası geçiren ve işine dönen işçi, iş sağlı̆̆1 ve güvenliği önlemlerine ne düzeyde uyacaktır" veya bunun da ötesinde "iş doyumu ve örgütsel bağlılık gibi işle ilgili tutumları nasıl etkilenecektir" gibi konuların araştırılması önerilebilir. 


\section{KAYNAKÇA}

Arkonaç, Sibel (2005), Sosyal Psikoloji, İstanbul:Alfa Yayınları.

Bilgin, Nuri (2003), Sosyal Psikoloji Sözlüğü: Kavramlar, Yaklaşımlar, İstanbul: Bağlam Yayınları.

Brewin, C. R. (1984), Attributions for industrial accidents: Their relationship to rehabilitation outcome, Journal of Social and Clinical Psychology, Vol. 2, No. 2, 156-164.

Demirbilek, Tunç (2005), İş Güvenliği Kültürü, İzmir:Dokuz Eylül Üniversitesi, İ̈BF Yayını.

Demirbilek, Tunç ve Çakır, Özlem (2008), Kişisel Koruyucu Donanım Kullanımını Etkileyen Bireysel ve Örgütsel Değiş̧kenler, Dokuz Eylül Üniversitesi İktisadi ve İdari Bilimler Fakültesi Dergisi, Cilt:23 Sayı:2, Y11:2008, ss:173-191.

Geller, Scott (2001), The psychology of safety handbook, New York:Lewis Publishers.

Gherardi, S., Nicolini, D. ve Odella, F. (1998), What do you mean by safety? Conflicting perspectives on accident causation and safety management in a construction firm, Journal of Contingencies and Crisis Management, 6, 202-212.

Glendon, A. Ian, G. Clarke, Sharon ve McKenna, Eugene (2006), Human safety and risk management, New York: Taylor\&Francis.

Goncalves, S. M., Agostinho da Siva, S., Lima, M., ve Melia, J. (2008), The impact of work accidents experience on causal attributions and worker behaviour, Safety Science, 46, 992-1001.
Gyekye, A. S. (2001), The self-defensive attribution theory revisited: A culturecomparative analysis between Finland and Ghana in the work environment. Helsinki, Finland: Helsingin Yliopisto Paino.

Gyekye, A. S. ve Salminen, S. (2007), Religious beliefs and workers' responsibility attributions for industrial accidents. Journal for the Study of Religion, 20,7386.

Gyekye, S. Ayim (2010), Occupational safety management: The role of causal attribution, International Journal of Psychology, 45:6, 405-416.

Gyekye, Seth Ayim (2005), Workers' Perceptions of Workplace Safety and Job Satisfaction, International Journal of Occupational Safety and Ergonomics, Vol. 11, No. 3, 291-302.

Gyekye, Seth Ayim (2006), Causal attributions for industrial accidents: A culturecomparative analysis, Journal of Intercultural Communications, 11, 2.

Hahn Susan E. ve Murphy, Lawrence R. (2008), A short scale for measuring safety climate, Safety Science, 46,10471066.

Hasle, P., Kines, P. ve Andersen, L. P. (2009), Small enterprise owners' accident causation attribution and prevention, Safety Science, 47, 9-19.

Håvold, Jon Ivar (2007), National cultures and safety orientation: A study of seafarers working for Norwegian shipping companies, Work \& Stress, 21:2, 173195.

Hofmann, D. ve Stetzer, A. (1998), The role of safety climate and communication in accident interpretation: Implications for learning from negative events, Academy of Management Journal, 41, 644657. 
Kağıçıbaşı, Çiğdem (2004), Yeni İnsan ve İnsanlar, İstanbul: Evrim Yayınları.

Kouabenan, D. R., Gilbert, D., Mendina, M., ve Bouzon, F. (2001), Hierarchical position, gender, accident severity, and causal attribution, Journal of Applied Social Psychology, 31, 553-575.

Liden, R., Stilwell, D. ve Ferris, G. (1996), The effects of supervisor and subordinate age on objective performance and subjective performance ratings, Human Relations, 48, 327-336.

Lingard, Helen ve Rowlinson, Steve (2005), Occupational Health and Safety in Construction Project Management, New York:Spon Press.

Manstead, Antony ve Hewstone Miles (1999), The Blackwell Encyclopedia of Social Psychology, Blacwell Publishing.

McSween, Terry E. (2003), Value-based safety process: Improving your safety culture with behavior-based safety, New Jersey: John Wiley.

Niza, C., Sila, S., ve Lima, M. L. (2008), Occupational accident experience: Association with workers' accident explanations and definition, Safety Science, 46, 959-971.

Rogers W., Stainton (2003), Social Psychology: Experimental and Critical Approaches, Philadelphia: Open University Press.

Rusch, Mark D., Dzwierzynski, William W., Sanger, James R, Pruit, Nathan T. ve Siewert, Andrea D. (2003), Return to work outcomes after work-related hand trauma: the role of causal attributions, Journal of Hand Surgery, Volume 28, Issue $4,673-677$.

Whittingham, Robert B. (2008), The blame machine:why human error causes accidents, London:Elsevier. 
